\title{
CASP6 wt Allele
}

National Cancer Institute

\section{Source}

National Cancer Institute. CASP6 wt Allele. NCl Thesaurus. Code C49557.

Human CASP6 wild-type allele is located within $4 \mathrm{q} 25$ and is approximately $15 \mathrm{~kb}$ in length.

This allele, which encodes caspase- 6 protein, plays a role in the cleavage and activation of both lamins and poly (ADP-ribose) polymerase (PARP) during apoptosis. Overexpression of the CASP6 gene promotes programmed cell death. 